\title{
Public Health-Based Policy on Stunting Prevention in Pati Regency, Central Java, Indonesia
}

\author{
Absori Absori ${ }^{1}$, Hartotok Hartotok ${ }^{1}$, Khudzaifah Dimyati $^{1}$, Heru Santoso Wahito Nugroho ${ }^{2}$, Arief Budiono $^{3}$, Rizka Rizka ${ }^{3}$ \\ ${ }^{1}$ Doctoral of Law, University of Muhammadiyah Surakarta, Surakarta, Indonesia; ${ }^{2}$ Department of Midwifery, Poltekkes Kemenkes \\ Surabaya, Indonesia; ${ }^{3}$ Department of Law, Faculty of Law, Universitas Muhammadiyah Surakarta
}

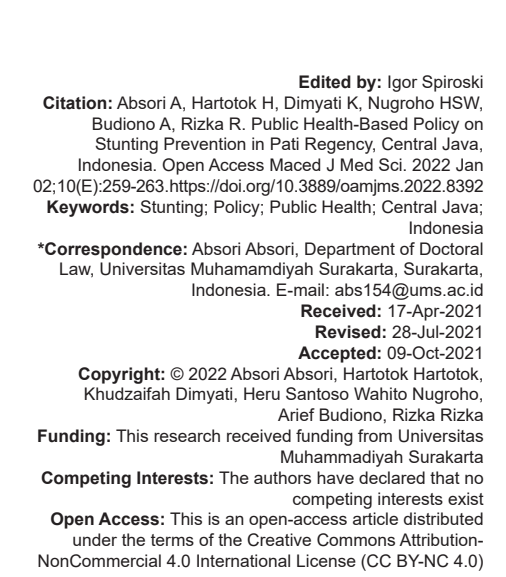

Abstract

BACKGROUND: In Indonesia, the Law on Long-Term Development Goals and the implementing regulations, namely the Health Law and the Food Law and their implementing regulations have stipulated nutritional adequacy for all ages including toddlers to prevent stunting. However, stunting still occurs, including in Pati Regency, Central Java Province.

AIM: This research aims to know and evaluate the stunting program from the Pati Regency, Province of Central Java, Indonesia and to found the solution.

METHODS: This is empirical (non-doctrinal) legal research which aims to analyze the public health-based local government policy in tackling the stunting problem in Pati Regency.

RESULTS: The results of the study indicate that there are eight stages of convergence actions from the public health-based local government policies to accelerate stunting prevention in the Pati Regency. However, the stunting prevention policy as a form of legal protection for children has not succeeded in reducing the stunting prevalence rate in this regency.

CONCLUSION: The conclusion of this research is beneficial to become an input for the Pati Regency Government Central Java Provincial Government in formulating and evaluating stunting prevention policies in their areas.

\section{Introduction}

Stunting prevention is prioritized in the Republic of Indonesia's President Joko Widodo's second term. Stunting is a chronic nutrition problem caused by intergenerational and multifactorial issues. Indonesians still regard small growth as caused by hereditary factors, though research shows that genetics only contribute $15 \%$. The main factors are nutrition, growth hormones, and repeated infections [1], [2]. Cigarette smoke and pollution also inhibit children's growth [3]. The nutrition status of babies and children is an indicator of public nutrition and an indicator of social health and welfare, as they are prone to malnutrition. Anthropometric nutrition assessment may reflect acute temporary conditions (underweight) or chronic ones (stunting) [4].

Children often lack nutrition, both qualitatively and quantitatively. Both macro (carbohydrate, fat, protein) and micro (zinc, calcium) nutrition sources are crucial for their development [5]. A study in Bogor to children 6-12 months old states that growth disturbances may be caused by the lack of single or combination micronutrition. Stunting affects children's growth, including their cognitive functions that may permanently affect their educative achievements. Thus, it is a predictor of a state's human resource quality [6].
The Presidential Decree No. 42 of 2013 on the National Movement of Nutrition Improvement supports coordinated and planned nutrition improvement for babies' 1000 first days of life. Stakeholders need to create inter-program (specific efforts) and inter-sectoral (sensitive efforts) activities as a more concrete effort. This study is carried out in Pati Regency, Central Java Province. The below shows that the stunting prevalence data in Pati is higher than the WHO and the national standards (Table 1) [7].

Semba et al. state that stunting is the most concerning nutritional problem in Central Java, with a $35,6 \%$ prevalence [8], while underweight and overweight have a prevalence of less than $20 \%$ [9]. Research on stunting is crucial as stunting is a direct indicator of lack of antenatal care quality, lack of pregnancy nutrition, and the presence of infectious diseases in children.

The regional government's public healthbased legal bases to prevent stunting in Pati Regency are Law No. 36 of 2009 on Health, Law No. 23 of 2014 on the Regional Government, the Governmental Decree No. 28 of 2004 on Food Resilience, Quality, and Nutrition, the Governmental Decree No. 33 of 2012 on Exclusive Breastfeeding, the Presidential Decree No. 42 of 2013 on the National Movement on the Acceleration of Nutrition Improvement and the 
Central Java Governor's Decree No. 34 of 2019 on the Acceleration of Stunting Prevention in Central Java.

Thus, it is clear that the Pati Regent prevents stunting with public health-based policies. With these legal bases, the Pati Regency Government issued the Regent's Decree No. 11 of 2020 on the Acceleration of the Decrease of Stunting in Pati Regency. Referring to this Decree the writer analyzes the actions to prevent stunting in Pati Regency. Thus, how are the public health-based Pati Regency policies to prevent stunting and their effectiveness?

\section{Methods}

This is empiric (non-doctrinal) legal research that compares the condition with the field and the constitutional regulations on public-health-based stunting prevention in Pati Regency with the conceptual and the comparison approaches [10]. Then, it uses the juridical-empiric or the sociological approaches [11] that connect the condition in the field and the ideal constitutional values [12]. This study is located in Pati Regency, Central Java as the stunting prevalence of Pati Regency is among the tenth worst in Central Java. Meanwhile nationally, Central Java is ranked the twelfth province with the worst stunting prevalence [13].

This research provides a novelty as it is focused on the Pati Regency policy that aims to prevent stunting and its effectiveness. This is the first research that is conducted to examine the health policy to prevent stunting in Pati Regency. The research was carried out for a year, from June 2020 to June 2021. It is conducted at Pati Regency, Central Java, Indonesia.

\section{Results}

Based on the Regent's Decree No. 11 of 2020 , the actions undertaken to decrease stunting are (Table 2) [14]:

(Table 3) [15]:

The eight convergent actions are as follows

These programs are not yet effective as the implementation are not serious. The things that need to be carried out are as follows (Table 4):

Data from 2020 show that 162 children experience stunting in Pati Regency. There are more stunting cases in lowlands compared to those in mountainsides (Table 5) [16]:

In villages, stunting is mostly caused by low education levels of mothers, lack of knowledge on nutrition, and the length of the sickness of stunting toddlers. On average, mothers from cities have higher education levels than those from villages. Thus, the former tend to have more knowledge on parenting [17], [18], [19], [20].

Table 1: Stunting prevalence data in Pati and its surroundings

\begin{tabular}{lll}
\hline No. & Area & Stunting prevalence (\%) \\
\hline 1. & Pati Regency & 33.9 \\
3. & Blora Regency & 23.8 \\
4. & Indonesia National & 30.7 \\
5. & WHO Standard & 20 \\
\hline
\end{tabular}

The stunting at stunting locus villages in Pati Regency is caused by some factors, including babies lack of nutrition, lack of proper parenting, hereditary (parents are short), toddlers do not obtain exclusive breastfeeding nor lack of early breastfeeding initiation, improper sanitation, babies with low birth weight, and pregnant mothers experience nutrition anemia [5], [21].

Table 2: Actions to prevent stunting based on the regent's decree no. 11 of 2020

\begin{tabular}{|c|c|c|}
\hline No. & Actions & Description \\
\hline 1. & $\begin{array}{l}\text { Implementing } \\
8 \text { convergent } \\
\text { actions }\end{array}$ & $\begin{array}{l}\text { Mapping and analyzing the stunting prevention program, formulating } \\
\text { activity plans, discourses, Regent's decree on village authority, } \\
\text { human development cadre training, stunting data management } \\
\text { system, assessment and publication, annual performance review }\end{array}$ \\
\hline 2. & Organization & A Pati Regency-level stunting convergence team is created \\
\hline 3. & Coordination & $\begin{array}{l}\text { The stunting convergence team coordinates with profession } \\
\text { organizations, university academics, religious leaders, etc. }\end{array}$ \\
\hline 4. & Teamwork & Required \\
\hline 5. & $\begin{array}{l}\text { Monitoring and } \\
\text { evaluation }\end{array}$ & Up to the village level \\
\hline 6. & Funding & $\begin{array}{l}\text { The Pati Regency Health Service obtains funds from the State } \\
\text { Expenditures and the Regional Expenditures I and II. }\end{array}$ \\
\hline
\end{tabular}

Thus, stunting is a combination of several factors. All stunting cases in Pati Regency are caused by a lack of nutritious food. Most stunting babies live in Klakahkasihan Village (37 cases), an underdeveloped village in Pati Regency. In underdeveloped villages, people usually have low spending power - including spending for health and nutrition [22].

Table 3: The implementation of the convergent actions

\begin{tabular}{|c|c|c|}
\hline No. & Convergent Action & Description \\
\hline 1. & $\begin{array}{l}\text { Mapping and } \\
\text { analyzing the } \\
\text { stunting prevention } \\
\text { program }\end{array}$ & $\begin{array}{l}\text { Based on the situational analysis in the locus villages, the } \\
\text { causes of stunting in Pati Regency are lack of nutritious } \\
\text { food }(100 \%) \text {, parenting }(83,33 \%) \text {, lack of early education } \\
\text { services }(66,67 \%) \text {, lack of exclusive breastfeeding } \\
\text { ( } 58,33 \%) \text {, lack of health security ( } 50 \%) \text {, babies with low } \\
\text { birth weight }(50 \%) \text {, lack of food provision at ho, e }(33,33 \%) \text {, } \\
\text { underweight pregnant women ( } 16,67 \%) \text {, no early initiation } \\
\text { of breastfeeding ( } 16,67 \%) \text {, poor household ( } 16,67 \%) \text {, } \\
\text { sanitation ( } 16,67 \%) \text {, pregnant women with anemia } \\
(16,67 \%) \text {, and pregnant women with preeclampsia }(8,33 \%) \text {. }\end{array}$ \\
\hline 2. & $\begin{array}{l}\text { Formulating activity } \\
\text { plans }\end{array}$ & $\begin{array}{l}\text { The plans are formulated with the Stunting Convergence } \\
\text { Team. The Regional State Organizations must provide } \\
\text { specific and sensitive intervention program budget. }\end{array}$ \\
\hline 3. & Stunting discourses & $\begin{array}{l}\text { The tiered discourses are carried out from the village to } \\
\text { the regency levels that involve the regional government, } \\
\text { non-governmental organizations, and society. }\end{array}$ \\
\hline 4. & $\begin{array}{l}\text { Regent's decree on } \\
\text { village authority }\end{array}$ & $\begin{array}{l}\text { The Regent's Decree No. } 38 \text { of } 2020 \text { on the Village } \\
\text { Authority to Integratively Prevent and Decrease Stunting }\end{array}$ \\
\hline 5. & $\begin{array}{l}\text { Human development } \\
\text { cadre training }\end{array}$ & $\begin{array}{l}\text { It exists in all villages based on a village deliberation to } \\
\text { facilitate stunting prevalence prevention. }\end{array}$ \\
\hline 6. & $\begin{array}{l}\text { Stunting data } \\
\text { management system }\end{array}$ & $\begin{array}{l}\text { The Pati government has identified the data required, } \\
\text { collected, and processed the data to guarantee accurate } \\
\text { information. }\end{array}$ \\
\hline 7 & $\begin{array}{l}\text { Assessment and } \\
\text { publication }\end{array}$ & $\begin{array}{l}\text { It is carried out by the Health Service and the } \\
\text { Communication and Information Service. All toddlers in } \\
\text { Pati Regency are assessed and the data are inputted } \\
\text { online. The data is referred to determine the stunting locus } \\
\text { villages in Pati Regency. }\end{array}$ \\
\hline 8 & $\begin{array}{l}\text { Annual performance } \\
\text { review }\end{array}$ & $\begin{array}{l}\text { There is annual review on the performance of the stunting } \\
\text { prevention programs at each city/regency locusses in } \\
\text { Central Java, managed by the Regional Development } \\
\text { Planning Agency. }\end{array}$ \\
\hline
\end{tabular}


Maryati, a mother with a stunting child stated, "I am sad that my child suffers from stunting. I understand that toddlers require nutritious food, but my husband has low income, and my income as a farmer is unstable." (Interview with Maryati, December $17^{\text {th }}, 2020$ ).

Table 4: Further actions to decrease stunting based on the pati regent's decree no. 11 of 2020

\begin{tabular}{|c|c|c|}
\hline No. & Further actions & Descriptions \\
\hline 1. & $\begin{array}{l}\text { Stunting mapping and } \\
\text { situation analyses }\end{array}$ & $\begin{array}{l}\text { It is not yet optimum in all villages, as it focuses on the locus } \\
\text { villages. Thus, the causes of Pati stunting are still unclear. }\end{array}$ \\
\hline 2. & $\begin{array}{l}\text { Featured activities and } \\
\text { best practices }\end{array}$ & Not yet available in Pati Regency \\
\hline 3. & Stunting causes & $\begin{array}{l}83,3 \% \text { of stunting is caused by parenting, but the Integrated } \\
\text { Service Posts are suboptimum as } 80 \% \text { of their four tables } \\
\text { are not yet implemented. The Education and Culture } \\
\text { Service must educate parents and teachers on parenting. }\end{array}$ \\
\hline 4. & Stunting publication & $\begin{array}{l}\text { Still suboptimum. It has not involved the Communication } \\
\text { and Information Services. }\end{array}$ \\
\hline 5. & $\begin{array}{l}\text { Integrated Service } \\
\text { Post Facilities and } \\
\text { Infrastructure }\end{array}$ & $\begin{array}{l}\text { Substandard, especially in non-locus villages. There needs } \\
\text { to be anthropometric measurement instruments. }\end{array}$ \\
\hline 6. & Stunting regulation & $\begin{array}{l}\text { The Pati Regency is still formulating a stunting regulation } \\
\text { to implement behavioral changes to prevent and decrease } \\
\text { stunting. }\end{array}$ \\
\hline 7. & $\begin{array}{l}\text { Community } \\
\text { empowerment }\end{array}$ & $\begin{array}{l}\text { The activeness of the health cadres and the Human } \\
\text { Development cadres are still suboptimum. }\end{array}$ \\
\hline
\end{tabular}

Sanikem, another mother with a stunting child stated, "My husband and I are farmers with irregular income. With three kids, it's a miracle that I can feed them three times a day. Thus, how can we provide well-nutrition foods?" (Interview with Sanikem, December 17 $\left.7^{\text {th }}, 2020\right)$.

Then, Siti Maimunnah, whose toddler does not suffer from stunting stated, "Thank God, my child doesn't suffer from stunting. My husband's income as a civil servant is not enough, that's why I opened this small restaurant. With it, I can provide simple nutritious food for my family." (Interview with Siti Maimunnah, December $\left.17^{\text {th }}, 2020\right)$.

From the interviews above, it can be concluded that the mothers of toddlers understand that their children require nutritious food. However, families with stunting children face challenges in fulfilling this need due to inadequate income. The government has provided nutritious biscuits for children with stunting, but the children tend to get easily bored with these biscuits [18].

Another cause of stunting that is inadequate in the locus village is improper parenting $(37,68 \%)$, for instance feeding additional foods to babies before they are 6 months old with wrong types of foods, and lack of attention over nutrition.

Table 5: The distribution of toddlers with stunting in stunting locus villages in pati regency on 2020 [17] [18] [19]

\begin{tabular}{llllll}
\hline No. & Village & District & Topography & \multicolumn{2}{c}{ Stunting Toddlers } \\
\cline { 5 - 6 } & & & Amount & Percentage \% \\
\hline 1 & Bogotanjung & Gabus & Lowlands & 8 & 7,21 \\
2 & Mulyoharjo & Pati & Lowlands & 4 & 1,69 \\
3 & Plangitan & Pati & Lowlands & 9 & 7,38 \\
4 & Klakahkasihan & Gembong & Mountainside & 37 & 7,34 \\
5 & Langenharjo & Margorejo & Lowlands & 21 & 15,11 \\
6 & Bungasrejo & Jakenan & Lowlands & 12 & 10,0 \\
7 & Kedalon & Batangan & Lowlands & 22 & 7,01 \\
8 & Mantingan & Jaken & Lowlands & 8 & 5,06 \\
9 & Karangrejo & Pucakwangi & Lowlands & 7 & 8,14 \\
10 & Sumur & Cluwak & Mountainside & 16 & 6,23 \\
11 & Tanggel & Winong & Lowlands & 2 & 2,27 \\
12 & Pakis & Tayu & Lowlands & 16 & 5,97 \\
Total & & & & 162 & 6,74 \\
\hline
\end{tabular}

Yanti, a mother whose child suffers from stunting stated, "I didn't know that giving foods too early may cause my child to experience stunting. I did so so that the child does not cry because I thought she cried because she was hungry." (Interview with Yanti, December $17^{\text {th }}, 2020$ ).

Pati Regency Regional Government's convergence policy to prevent and handle stunting is carried out through integrated specific and sensitive nutrition interventions. National experience shows that these interventions are key to successfully improving nutrition, improving children's growth and development, and preventing stunting. Specific nutrition intervention targets these stunting causes: (1) food and nutrition adequacy, (2) food administration, treatment, and parenting, and (3) healing infections/diseases. There are three specific nutrition groups, namely [23]:

1. Prioritized intervention. It is identified as the most influential to prevent stunting and it is aimed to reach all priority targets.

2. Supporting intervention. It affects nutrition and other health issues concerning stunting and is carried out after the priority intervention is fulfilled.

3. Conditional prioritized intervention is carried out according to certain conditions including emergency disaster conditions (emergency nutrition programs).

Sensitive nutrition interventions in Pati include (1) increasing access to nutritious foods, (2) increasing awareness, commitment, and practice to increase the nutrition of mothers and children, (3) increasing nutrition and health service quality and access, and (4) increasing the provision of clean water and sanitation.

"The prioritized policy on stunting prevention in Pati Regency is sensitive nutrition intervention that is carried out outside of the Pati Regency Health Service. It basically includes increasing the access to nutritious foods; increasing awareness, commitment, and practice to increase the nutrition of mothers and children; increasing nutrition and health service quality and access; and increasing clean water and sanitation facilities." (Interview with Edy Siswanto, Head of the Health Service of Pati Regency, July $8^{\text {th }}, 2020$ ).

This statement is agreed upon by Nurwono, Secretary of the Health Service of Pati Regency, who said, "Yes, sensitive nutrition intervention is prioritized in Pati Regency. Even though the contents have been determined, it includes increasing access to nutritious foods; increasing awareness, commitment, and practice to increase the nutrition of mothers and children; increasing nutrition and health service quality and access; and increasing clean water and sanitation facilities." (Interview with Nurwono, Secretary of the Health Service of Pati Regency, July $\left.8^{\text {th }}, 2020\right)$. 


\section{Discussion}

Sensitive nutrition intervention is prioritized in Pati Regency, outside of the Health Service. It includes the increase of nutritious food; increasing awareness, commitment, and practice of nutrition guiding for mothers and children; increasing nutrition and health service quality and access; and also providing clean water and sanitation facilities.

Then, convergence is defined as a coordinated and integrated intervention to priority household and geographic areas to prevent stunting by combining various resources. In reality, the eight convergent policies are ineffective as the implementation is not complete, though they are well-formulated. The Pati Regency government needs to make sure of its implementation to prevent and decrease stunting cases.

Some studies on stunting in Pati Regency, Central Java have been conducted. One of them was carried out by Aeda Ernawati, which was entitled, "Description of Causes of Stunting in Toddlers in Lokus Village, Pati Regency". It discusses the causes of the rampant cases of stunting in Lokus Village, Pati Regency. The results showed that the causes of stunting in Lokus village in Pati District were: (1) inadequate intake; (2) inadequate parenting; (3) low parental height; (4) not getting exclusive breastfeeding; (5) not getting early initiation of breastfeeding; (6) lack of environmental sanitation; (7) LBW; (8) Mother during pregnancy has anemia. Stunting was not caused by a single factor, but a combination of several causes. Therefore, all components of society should cooperate to reduce stunting cases. This study did not discuss the policies to prevent stunting [16].

Another research was conducted by Anugraheni and Kartasurya, entitled, "Stunting Risk Factors to Children 12-36 Months Old in Pati District, Pati Regency". It is found that the risk factors of stunting to children of 12-36 months in Pati District, Pati Regency are prematurity and short birth length. Other factors include the lack of nutrition as the parents or the guardians are poor and that they are unable to supply nutritious food and the lack of the mothers' understanding of the importance of breastmilk [5].

Based on the variables above, if it is linked to the context of the current government policy in the health sector, Indonesia focuses on policies to prevent stunting. According to the Basic Health Research from the Ministry of Health, Indonesia is in the top five countries with a stunting prevalence of $30.8 \%$ in 2018 . It shows that many toddlers lack nutrition. Even so, it has decreased from the stunting prevalence of $37,2 \%$ in 2013. Thus, the government issued some regulations that prioritize the prevention and the eradication of stunting. This is crucial as stunting imposes great implications on the development of Indonesian human resources.
The policies issued by the Pati Regency government are very interesting and they are very structured. If the policies are implemented holistically, it is estimated that the rate of stunting and malnutrition may decrease. Unfortunately, the stunting prevalence in this Regency has not decreased. Thus, the Pati Regency government must review the planning and the implementation of the health policies to effectively prevent stunting.

\section{Conclusion}

There are many cases of stunting in Pati Regency, Central Java Province, Indonesia, due to babies lack of nutrition, lack of proper parenting, hereditary (parents are short), toddlers do not obtain exclusive breastfeeding nor early initiation of breastfeeding, improper sanitation, babies with low birth weight, and pregnant mothers experience nutrition anemia. The practical implication of this research is that the 8-stage policies of the Pati Regency government are not effective. It is not due to errors in formulating the program, but it is because the policies are not holistically implemented. Some stages or policies are unfulfilled. To handle this, the Pati Regency Government implemented eight convergent actions, namely mapping and analyzing the stunting prevention program, formulating activity plans, discourses, Regent's decree on village authority, human development cadre training, stunting data management system, assessment and publication, annual performance review. The measures against stunting need to be optimized by progressively implementing these well-conceived programs.

\section{References}

1. Brinkman HJ, de Pee S, Sanogo I, Subran L, Bloem MW High food prices and the global financial crisis have reduced access to nutritious food and worsened nutritional status and health. J Nutr. 2010;140(1):153S-61S. https://doi.org/10.3945/ jn.109.110767 PMid:19939996

2. The Indonesian Ministry of Health. Public Nutrition Guideline Work Plan 2013. Jakarta: Erlangga; 2013. p. 64.

3. Kyu HH, Georgiades K, Boyle MH. Maternal smoking, biofuel smoke exposure and child height-for-age in seven developing countries. Int J Epidemiol. 2009; 3(5):1342-50. https://doi. org/10.1093/ije/dyp253 PMid:19622677

4. Sari M, de Pee S, Bloem MW, Sun K, Thorne-Lyman AL, Moench-Pfanner $\mathrm{R}$, et al. Higher household expenditure on animal-source and nongrain foods lowers the risk of stunting among children 0-59 months old in Indonesia: Implications of rising food prices. J Nutr. 2010;140(1):195S-200. https://doi. 
org/10.3945/jn.109.110858

PMid:19939994

5. Anugraheni HS, Kartasurya MI. Stunting risk factors to children 12-36 months old in Pati district, Pati Regency. J Nutr Coll. 2012;1(1):30-7.

6. UNICEF. Improving Child Nutrition, the Achievable Imperative for Global Progress. New York: UNICEF; 2013.

7. World Health Organization. Reducing Stunting in Children: Equity Considerations for Achieving the Global Nutrition Targets 2025. Switzerland: World Health Organization; 2018. p. 32.

8. Rah JH, Akhter N, Semba RD, de Pee S, Bloem MW, Campbell AA, et al. Low dietary diversity is a predictor of child stunting in rural Bangladesh. Eur J Clin Nutr. 2010;64(12):13938. https://doi.org/10.1038/ejcn.2010.171 PMid:20842167

9. Ministry of Health. Basic Health Research 2010. Jakarta: Ministry of Health; 2010. p. 24.

10. Nugroho HS, Handoyo H, Prayitno H, Budiono A. Sort elements based on priority, in order to improve the quality of e-learning in health using difficulty-usefulness pyramid with weighting (DUP-We). Int J Emerg Technol Learn. 2019;14(180):186-93.

11. Yuspin W, Absori A, Nurhayati N. The establishment of participatory regional regulations based on local wisdom. Hum Soc Sci Rev. 2019;7(3):92-6.

12. Dimyati K, Nashir H, Elviandri E, Absori A, Wardiono K, Budiono A. Indonesia as a legal welfare state: A prophetic-transcendental basis. Heliyon. 2021;7(8):1-8.

13. Armini LP. Denpasar City Health Service Profile 2018. Denpasar:
Health Service; 2019. p. 42.

14. Ernawati A. Description of low birth weight in Pati regency J Litbang. 2015;5(1):46-55. https://doi.org/10.33658/jl.v11i1.60

15. Ernawati A. Analysis of nutrition deficit prevention program implementation to toddlers in Jakenan community health centre, Pati regency. J Litbang. 2019;15(1):39-50.

16. Ernawati A. Description of causes of stunting in toddlers in Lokus village, Pati regency. J Litbang. 2020;16(2):77-94.

17. Ernawati $A$. The role of health services in exclusive breastfeeding: The study of civil servants in Pati regency. J Litbang. 2014;10(2):133-42. https://doi.org/10.33658/jl.v10i2.85

18. Pati Regency Health Service. Health Profile of Pati Regency 2018. Pati: Health Service; 2018.

19. Siddiq NA. Infectious diseases and consumption pattern with nutrition status deficit based on weight and age of 6-24-monthold toddlers in Tanah Sepenggal community health centre work area. J Gizi Nutrisi. 2015;1(1):1-8.

20. Lusita AP, Suyatno, Rahfiludin MZ. Differing characteristics of stunting toddlers in villages and cities on 2017: A study to 24-59-month-old children at Gabus II and Pati II community health centre work areas, Pati regency. J Kesehatan Masyarakat. 2017;5(4):600-12.

21. Regional Development Planning Agency. Pati in Numbers. Pati: Bappeda; 2020. p. 36-7.

22. Chusniatun C, Dimyati K, Absori A, Budiono A. Legal protection for child criminals at the juvenile detention center: Study of psychiatric health. J Glob Pharm Technol. 2020;12(8):91-5.

23. Sukamto AR. Malnutrition risk factors of toddlers in Margorejo, Pati Regency, 2019. 2020. Thesis. Yogyakarta: UII; 2020. 